Article

\title{
The Challenge of Governing Africa's New Agricultural Investment Landscapes: An Analysis of Policy Arrangements and Sustainability Outcomes in Ethiopia and Nigeria
}

\section{George C. Schoneveld}

Center for International Forestry Research (CIFOR), P.O. Box 30677, Nairobi 00100, Kenya; E-Mail: g.schoneveld@cgiar.org; Tel.: +254-20-722-4121

Academic Editor: Pablo Pacheco

Received: 16 October 2014 / Accepted: 23 December 2014 / Published: 30 December 2014

\begin{abstract}
In the context of globalization, market liberalization, and deregulation, many African governments are embracing the potential of private agricultural investment to address structural issues within their agricultural economies. Sustainably integrating these investments into target landscapes, however, poses a number of governance challenges since it requires careful reconciliation of competing needs, priorities, and land uses. This paper examines the effectiveness of existing policy arrangements in managing these conflicts within two environmentally significant investment landscapes, the Oban-Korup Forest Block, Nigeria, and Lower Baro-Akobo River Basin, Ethiopia. Findings reveal that investments tend to conflict with socially and environmentally valuable land uses, largely as a result of institutional failings. The paper identifies a number of underlying institutional challenges that need to be addressed in order to achieve sustainable development objectives within Africa's many emerging investment landscapes. Findings have relevance for the development of sustainable landscape governance systems and the alignment of global governance innovations with landscape-level policy arrangements.
\end{abstract}

Keywords: landscape; governance; sustainability; large-scale land acquisition; agricultural investment; Nigeria; Ethiopia

\section{Introduction}

Since the 2007-2008 food and energy price crisis, favorable conditions within soft commodity markets and an increasing imperative to control upstream value chain activities to minimize exposure to 
global price shocks has stimulated new investments in the cultivation of cash crops $[1,2]$. Because of an abundance of cheap agro-ecologically suitable land, Africa has in recent years become a prime agricultural investment destination [3,4]. Considering comparatively high poverty rates in rural areas, low productivity and output, and declining public spending on the agricultural sector as a result of structural adjustment reforms [5,6], most African governments are eagerly embracing this new influx of capital; for example, since they consider this to contribute to improving access to inputs, uptake of modern farming practices, global market articulation, and rural employment opportunities [3,7].

This trend, however, sits uncomfortably with the sustainable development and inclusive green growth discourse that is increasingly shaping national development plans and strategies [8]. Since this discourse is premised on the need to reconcile macro-economic growth, social equity, and natural resource conservation, the large environmental and social footprint of, for example, monoculture plantations in historical centers of production in Latin America and Southeast Asia has raised important questions about the potential negative trade-offs of promoting such production models in Africa [2,8,9]. Due to insecure property rights, the abundance of inadequately protected high conservation value ecosystems, comparatively weak societal embeddedness of the state, and limited domestic planning capacity [2,10], early evidence is suggesting that most new agricultural investments in Africa compete with existing land uses, leading to displacement and dispossession, disruptions to traditional systems of production, and conversion of environmentally significant landscapes [11].

These negative sustainability outcomes are largely a product of poor governance $[2,6,11]$. Therefore, in order to more effectively align agricultural investments in Africa with local development policies and generic sustainable development goals, careful examination of the various policy arrangements relevant to sustainable development is required. Since agricultural investments are often spatially concentrated in strategic and agro-ecologically suitable areas, an analysis of these arrangements would need to account for processes at varying scales. Due to the context-specificity, it is important, for example, that when more sustainable land allocation and management policies and practices are being developed, landscape-level realities, priorities, and challenges are incorporated [12,13]. Analysis of policy arrangements at a national level, for example, would not adequately capture the diversity of state and non-state actors that influence policy processes at the landscape level, and ultimately have significant bearing on outcomes $[13,14]$. A landscape approach should therefore be adopted.

This paper analyzes the performance of policy arrangements relevant to two environmentally significant landscapes in Ethiopia and Nigeria in integrating new agricultural investments and existing land uses. These two landscapes can be considered to be emergent "investment landscapes"; defined here as landscapes that are in the process of undergoing profound social, economic, environmental, and political transformations as a result of productive investment influx. In its analysis, this paper highlights a number of underlying institutional challenges related to reconciling competing land use pressures and priorities pertinent to the sustainable development of Africa's numerous emerging investment landscapes, and to sustainable landscape governance, more generally.

The following section examines the attributes of ideal-typical landscape governance regimes and proposes an appropriate approach for examining the relationship between governance and sustainability outcomes. Subsequently, findings from research conducted in the Oban-Korup Forest Block in Nigeria and the Lower Baro-Akobo River Basin in Ethiopia will be presented, followed by a discussion on 
structural institutional challenges and a conclusion on the implications of findings for the sustainable development governance debate.

\section{Background}

\subsection{Ideal-Typical Governance of Investment Landscapes}

In the context of ongoing processes of globalization, market liberalization, decentralization, and deregulation, development policy and planning are no longer the exclusive domain of the national state. This is evidenced by the increasingly prominent role of multilateral treaties relating to, for example, environment, trade, and human rights, and supranational trade and policy blocs in shaping national policy and regulatory processes $[15,16]$. Similarly, economic integration and processes of deregulation (for example, in the context of structural adjustment reforms) have fundamentally altered discourse of many developing countries on the virtues of international trade and investment. With the level of foreign direct investment (FDI) to developing countries in the 1980s surpassing official development assistance, governments increasingly began to view transnational corporations and FDI more generally as a solution to issues of poverty rather than as the problem $[17,18]$. The consequent decline in regulatory leverage of the nation-state over the corporation and the increasing incongruence of hard legalistic approaches with neo-liberal principles led to the emergence of "softer" self- and co-regulation approaches spearheaded by private sector and civil society groups to managing corporate conduct and resolving public good problems arising from deregulation [19,20]. This has included, for example, corporate social responsibility and market-based instruments, such as voluntary multi-stakeholder certification systems. More generally, private actors at various scales are seen as playing a more prominent role in policy, polity, and politics [21]. In the mainstream academic debate this has been characterized as a shift from hierarchical state-centric modes of governance to more society-centric modes of governance, with a more prominent regulatory role for non-state actors [14,21,22].

The emerging international discourse on inclusive and green growth is increasingly beginning to draw attention to the need to capitalize on potential synergies between what are often conflicting policy objectives relating to social equity, economic growth, and natural resource conservation [8]. Therefore, with a growing focus on socio-ecological systems, landscape approaches are increasingly being adopted to examine the interactions between these objectives and associated outcomes [13,23]. In such approaches, the landscape is typically viewed as the spatial-temporal dimension of human-environment interactions [16]. Although landscapes are by definition a social construction and their spatial scale subject to varying interpretation, for the purpose of a paper on landscape governance, a landscape can be viewed as a specific ecological system that is subject to institutional interventions framed by specific place-bound priorities and actions [13,24]. Accordingly, the landscape can be seen as a unit of analysis and as a unit of intervention, as is discussed in great detail in this Special Issue's Editorial.

In the context of sustainable development governance, high spatial and temporal diversity of socio-ecological systems mean there is a growing need for governance modes and arrangements that capture spatially explicit realities, challenges, and priorities. Although examples of successful landscape governance are scarce [12], evaluation of normative literature on landscape governance and on global and environmental governance, more generally, does highlight numerous governance characteristics that 
are considered especially amenable to realizing sustainability outcomes. Firstly, landscape governance systems should value and accommodate the (competing) interests of multiple actors [12,21]. The importance of meaningful participation, equitable power distribution, and ownership of policy processes by state and non-state actors, such as civil society and the private sector, and also by informal institutions are all considered to be instrumental $[12,14]$. The second commonly cited dimension relates to the multi-scale focus of actors in or with an interest in a landscape. Different actors operate at different scales due to varying jurisdictional authority (e.g., local, regional, national, and supranational government) and spatial interests (e.g., civil society groups campaigning on global issues and local issues), which all have a bearing on outcomes in a landscape. Actors from one level (e.g., the local level) may also participate in decision-making processes at another level (e.g., the national level) $[14,16]$. In the context of landscape governance, balancing of top-down and bottom-up decision-making processes can be achieved when governance activities are, for example, organized in multiple nested layers $[25,26]$ and capitalize on bridging organizations that link different actors and governance levels [27]. Finally, sustainable landscape governance regimes are said to require horizontal integration through appropriate cross-sectoral coordination so that they reconcile competing or complementary stakeholder interests, exploit diverse expertise, and develop holistic and integrated landscape-level policies and strategies [12,21].

Various relevant governance modes have been proposed that emphasize these multi-scale, multi-actor, and cross-sectoral dimensions, such as, for example, interactive governance [22], open co-governance [28], network governance [29], deliberative governance [30], and polycentric governance [26]. Ideal-typical governance modes are, however, rarely found in practice, with most governance arrangements displaying hybrid characteristics $[21,22]$.

\subsection{Policy Arrangements for Sustainable Governance of Investment Landscapes}

This paper applies the policy arrangement approach (PAA) as an analytical tool for assessing how well investment landscapes are governed in line with sustainable landscape objectives. The PAA is an institutionalist approach that suggests that interactions between actors in relation to certain policy processes evolve into stable patterns, both in terms of organization and content [31]. Such patterns within a policy domain constitute the policy arrangement. This differs conceptually from governance since these are typically shaped by a concrete and sector-specific policy direction [28]. In many contexts, policy arrangements are said to be continuously in flux, especially since these are viewed as increasingly multi-level and transnational in character [31].

The structure of the policy arrangement can be analyzed through four interrelated dimensions, which are drawn primarily from network theory and discourse analysis [32]. These comprise:

- The governmental and non-governmental actors and their coalitions involved in the policy domain.

- The division of power and influence between actors.

- The rules of the game in operation, in terms of formal procedures such as regulations and informal rules of interaction.

- The policy discourses, including the views and narratives of the actors involved. 
This analytical distinction and actor emphasis is helpful in systematically identifying the nature of interactions between actors involved in the management and regulation of investment landscapes and the structural factors that shape these. Linking this analysis with one of sustainability outcomes enables us to isolate aspects of a policy domain that (re)produce both desirable and undesirable outcomes. This in turn allows for more effective policy interventions targeted at concrete organizational and/or substantive problems and to evaluate the feasibility of incorporating new policy innovations into existing policy arrangements.

In the context of sustainable landscape governance, policy arrangements need to be analyzed for each individual policy domain, particularly when researched landscapes are characterized by fragmented sectoral responsibilities and a lack of explicitly articulated landscape governance systems. This analysis then helps to highlight organizational and substantive conflicts and tension not only within but also between policy domains that need to be addressed in the development of more multi-actor, multi-scale, and cross-sectoral landscape governance systems. Conversely, where there are overlapping policy arrangements between domains, such an approach also contributes to identifying those actors and coalitions that are well placed to function as bridging organizations when developing more integrated systems.

As highlighted by Schoneveld and Zoomers [8], effectively aligning investments with sustainable development objectives requires that governance systems address two key proximate challenges, namely mitigation of undesirable outcomes and capture of investment co-benefits. Therefore, policy arrangements need to be viewed in relation to their achievements and outcomes in these two areas. Since expertise and mandates vary across policy domains, it is the collective outcome of multiple complementary (or sometimes competing) policy domains that determine the net effectiveness of a landscape governance system in realizing sustainable development objectives within investment landscapes.

In this research, analysis focused on four key policy domains integral to sustainable development (Table 1). The first pertains to policy processes that are targeted specifically at the promotion and regulation of (international) trade and investment. This tends to directly involve ministries of commerce, trade, and economic planning, and often-dedicated Investment Promotion Agencies (IPA) that are typically either (quasi-)autonomous public bodies or subunits of one of these ministries. In many cases, ministries responsible for certain economic sectors, such as mining, agriculture, and energy, are mandated to take on some of these responsibilities. This policy domain is largely involved in creating enabling conditions for investment, allocating investment licenses, and ensuring investments align with national economic development objectives (e.g., by promoting investments in priority sectors and activities). Though traditionally having a largely promotional orientation, in recognition that the benefits of investment are often inadequately internalized, these actors are increasingly taking on more regulatory functions [33].

The second policy domain relates to land-use planning and identification. The overarching objective is to facilitate the allocation of land to uses that provide optimal societal benefits. Within investment landscapes, this primarily involves ensuring land for investment complements rather than conflicts with other established and planned land uses, such as conservation and agriculture. Since it involves the integration of physical, social, economic, and environmental objectives, land-use planning requires cross-sectoral cooperation, though responsibilities tend to reside within ministries of land and housing and sometimes also of environment. 
Table 1. Typical roles of key policy domains in relation to investment governance.

\begin{tabular}{|c|c|c|}
\hline \multirow{2}{*}{ Policy Domain } & \multicolumn{2}{|r|}{ Typical Roles } \\
\hline & Impact Mitigation & Co-Benefit Capture \\
\hline $\begin{array}{l}\text { Trade } \\
\text { and Investment }\end{array}$ & $\begin{array}{l}\text { - } \text { Restrict opportunities for capital flight } \\
\text { and tax avoidance } \\
\text { - } \\
\text { Restrict investments that compete with } \\
\text { domestic enterprises and sectors of } \\
\text { national interest } \\
\text { - } \quad \text { Promotion of quality standards } \\
\text { Prevent underpricing of commodities } \\
\text { that destabilize domestic markets }\end{array}$ & 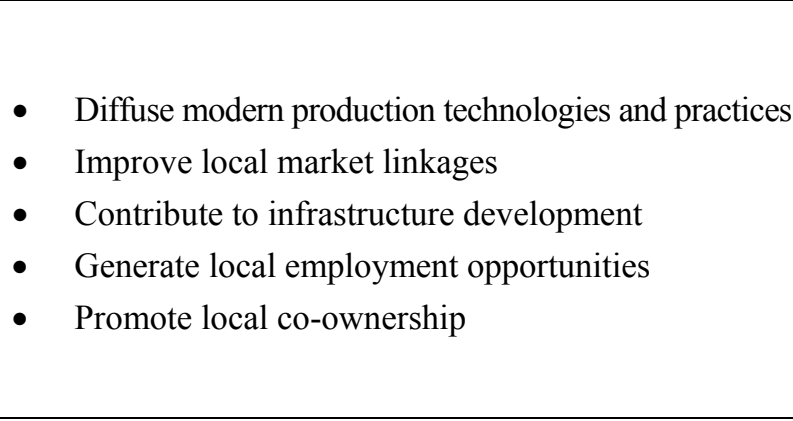 \\
\hline $\begin{array}{l}\text { Land } \\
\text { use planning }\end{array}$ & $\begin{array}{l}\text { - Minimize land-use conflicts through } \\
\text { allocation of genuinely available lands } \\
\text { Limit environmentally and socially } \\
\text { detrimental investments } \\
\text { Minimize enclaves of foreign } \\
\text { investment that do not link with } \\
\text { domestic actors }\end{array}$ & $\begin{array}{l}\text { - } \quad \text { Enhance land use efficiency } \\
\text { - } \quad \text { Establish complementarities between land uses } \\
\text { - Steer local economic development in priority sectors } \\
\text { - }\end{array}$ \\
\hline Land tenure & $\begin{array}{l}\text { Protection of (customary) land rights } \\
\text { from involuntary expropriation } \\
\text { - Disbursement of adequate compensation }\end{array}$ & $\begin{array}{l}\text { - Meaningful incorporation of affected land users into } \\
\text { investment projects } \\
\text { - } \quad \text { Equitable distribution of land revenues }\end{array}$ \\
\hline Environment & 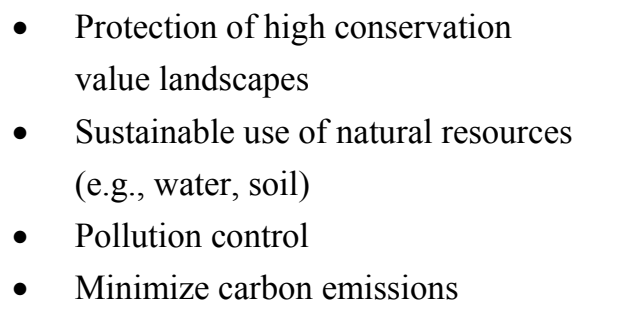 & $\begin{array}{l}\text { - Rehabilitation of degraded and unproductive lands } \\
\text { - Diffusion of environmentally-friendly technologies } \\
\text { and practices } \\
\text { - Development of biodiversity and carbon } \\
\text { offset markets }\end{array}$ \\
\hline
\end{tabular}

The third policy domain, land tenure, forms an important legal foundation for land-use planning and for sustainable development more generally. It principally involves the allocation and protection of customary and/or statutory land rights. Land tenure arrangements shape how well diverse ex ante user claims are respected in case of land acquisition and conversion by investors. This is usually the domain of ministries of land, though in the African context it also often involves some form of devolution to district-level and customary land management authorities.

The fourth policy domain relates to environmental management that concerns, amongst other issues, pollution control, water management, conservation, wildlife and forestry. The objective here is to ensure long-term sustainable resource management and use. Responsibilities typically fall under the auspices of ministries of environment and their subunits, such as environmental protection agencies (EPA), water authorities, and forestry commissions.

\section{Case Study Overview and Methodological Approach}

This research is based on research activities conducted between July 2011 and March 2013 in two landscapes: Oban-Korup forest block in Cross River State (CRS), Nigeria, and lower Baro-Akobo River Sub-basin in Gambella Regional State, Ethiopia. The two landscapes were selected because they 
represent important forest frontier areas that are becoming increasingly important hotspots for agricultural investment. As will be highlighted below, since these landscapes encapsulate important social, economic, and environmental land uses, examining here how these competing interests are reconciled through existing policy arrangements could be informative to the emerging landscape governance discourse.

Oban-Korup is a tropical high forest block that covers most of southern CRS and extends into neighboring Cameroon [34]. Home to large numbers of endangered mammal species, it is considered to be one of Africa's most significant biotic reserves [35]. The lower Baro-Akobo River Sub-Basin, part of the Eastern Nile Basin, is located, in the humid tropical lowlands of southeast Ethiopia. The landscape develops from dense dryland forests in the east into wooded grasslands and seasonal floodplains in the west [36]. The landscape is notable for harboring the second largest mammal migration in Africa [37].

The formal economy within the Oban-Korup landscape has long been structured around natural resource extraction, notably logging and quarrying, and state-owned rubber, cocoa, and oil palm plantations. Much of the population is agrarian, involved primarily in shifting cultivation and forest-based livelihood activities such as hunting and harvesting of non-timber forest products (NTFPs). Cotton production through state-owned enterprises was long one of the few industrial activities in lower Baro-Akobo. Traditional livelihood systems remain prevalent, involving shifting cultivation and harvesting of NTFPs in the forested east and agro-pastoralism based on cattle herding, fishing, and opportunistic flood-retreat agriculture in the west.

By virtue of their fertile soils, vast water resources, and comparatively low population densities (93 persons per $\mathrm{km}^{2}$ in CRS and 10 persons per $\mathrm{km}^{2}$ in Gambella), since the early 2000s, both landscapes have emerged as prime agricultural investment destinations. Between 2000 and 2013, an estimated 302,716 ha of land was transferred to agricultural investors in CRS (equivalent to $15.1 \%$ of the surface area) and 390,812 ha in Gambella (equivalent to $13.2 \%$ of the surface area). In CRS, these investments are primarily for tree-crop plantations such as rubber and oil palm, and in Gambella cotton and rice. In both landscapes, the investments have so far involved exclusively plantation-based production models, rather than more inclusive production models such as, for example, contract or tenant farming.

As will be further elaborated in the following section, these developments are taking place in a policy environment that is increasingly seeking to capitalize on the potential of agricultural FDI and private capital formation more generally to realize economic diversification and agricultural modernization and commercialization objectives. In both Ethiopia and Nigeria, these policies are implemented through a federal system of government that has involved formal devolution of decision-making authority to regions and districts through political, fiscal, and administrative decentralization, as is enshrined in their, respective, 1995 and 1979 Constitutions. In view of the ideal-typical governance modes discussed above, these structures arguably form an important foundation for more integrated landscape governance systems. Despite this, the governance context in both countries does display marked differences; the Ethiopian government, for example, exhibits authoritarian tendencies with circumscription of some fundamental civil liberties, while the Nigerian government is infamous for deeply entrenched oil rentier politics.

Research activities in the landscapes firstly involved collection of relevant secondary information to reconstruct investment establishment processes and development trajectories. This information includes community-company contracts, land titles, privatization agreements, feasibility studies, environmental 
and social impact assessments, cadastral maps, official government gazettes, various archival materials, and investment data. Semi-structured interviews were conducted with representatives from most government entities involved in the four policy domains and any non-governmental entities with, for example, a co-regulatory, lobbying, or countervailing role. This included interviews with, amongst others, 67 government representatives, 11 civil society organization (CSO) representatives, 12 investors, and 24 traditional authorities. (see Table 2 for an overview of the different government entities involved in the four policy domains). Since many investors, CSOs, and traditional authorities expressed a desire to remain anonymous, their identities will not be revealed in this paper. Snowball sampling was adopted as an appropriate sampling method since each interview tended to yield new information regarding the role of certain individuals or groups involved.

The assessment of sustainability outcomes involved the application of qualitative approaches, such as participatory ranking and focus group discussions, with affected stakeholder groups. These include employees and displaced or dispossessed households, disaggregated by locally differentiating socio-economic status (e.g., women, youths, migrants). Twenty communities were included in the sample, selected on the basis of proximity to investment. This was complemented by remote-sensing analysis to establish the scale and nature of land-use change dynamics associated with investment. The land use/investment distribution maps were constructed using Global Positioning System field samples and the digitalization of leasehold, cadastral, and protected area maps.

Table 2. Government entities involved in the different policy domains.

\begin{tabular}{|c|c|c|}
\hline \multirow{2}{*}{ Policy Domain } & \multicolumn{2}{|c|}{ Responsible Government Entities } \\
\hline & Ethiopia & Nigeria \\
\hline $\begin{array}{l}\text { Trade and } \\
\text { Investment }\end{array}$ & $\begin{array}{ll}\text { - } & \text { Ethiopian Investment Agency (EIA) } \\
\text { Gambella Investment Agencies (GIA) } \\
\text { - } & \text { Agricultural Investment Land } \\
& \text { Administration Agency (AILAA) } \\
\text { - } & \text { Ministry of Finance and Economic } \\
\text { Planning (MOFED) }\end{array}$ & $\begin{array}{ll}\text { - } & \text { CRS Governor's Office } \\
\text { - } & \text { Nigerian Investment Promotion } \\
& \text { Commission (NIPC) } \\
\text { - } & \text { CRS Investment Promotions Bureau (IPB) } \\
\text { - } & \text { CRS Privatization Commission } \\
\text { - } & \text { CRS Ministry of Agriculture and Natural } \\
& \text { Resources (MANR) } \\
\text { - } & \text { Federal Ministry of Agriculture and } \\
& \text { Rural Development (MOARD) }\end{array}$ \\
\hline Land use planning & $\begin{array}{ll}\text { - } & \text { Federal Ministry of Agriculture (MOA) } \\
\text { - } & \text { Agricultural Investment Land } \\
\text { - } & \text { Administration Agency (AILAA) } \\
\text { Ethiopian Wildlife Conservation } \\
\text { Authority (EWCA) } \\
\text { - } \\
\text { Gambella Land Utilization, } \\
\text { Administration and Environmental } \\
\text { Protection Authority } \\
\text { - } \\
\text { Gambella Regional Council }\end{array}$ & $\begin{array}{l}\text { - CRS Ministry of Agriculture and Natural } \\
\text { Resources (MANR) } \\
\text { - CRS Planning Commission }\end{array}$ \\
\hline
\end{tabular}


Table 2. Cont.

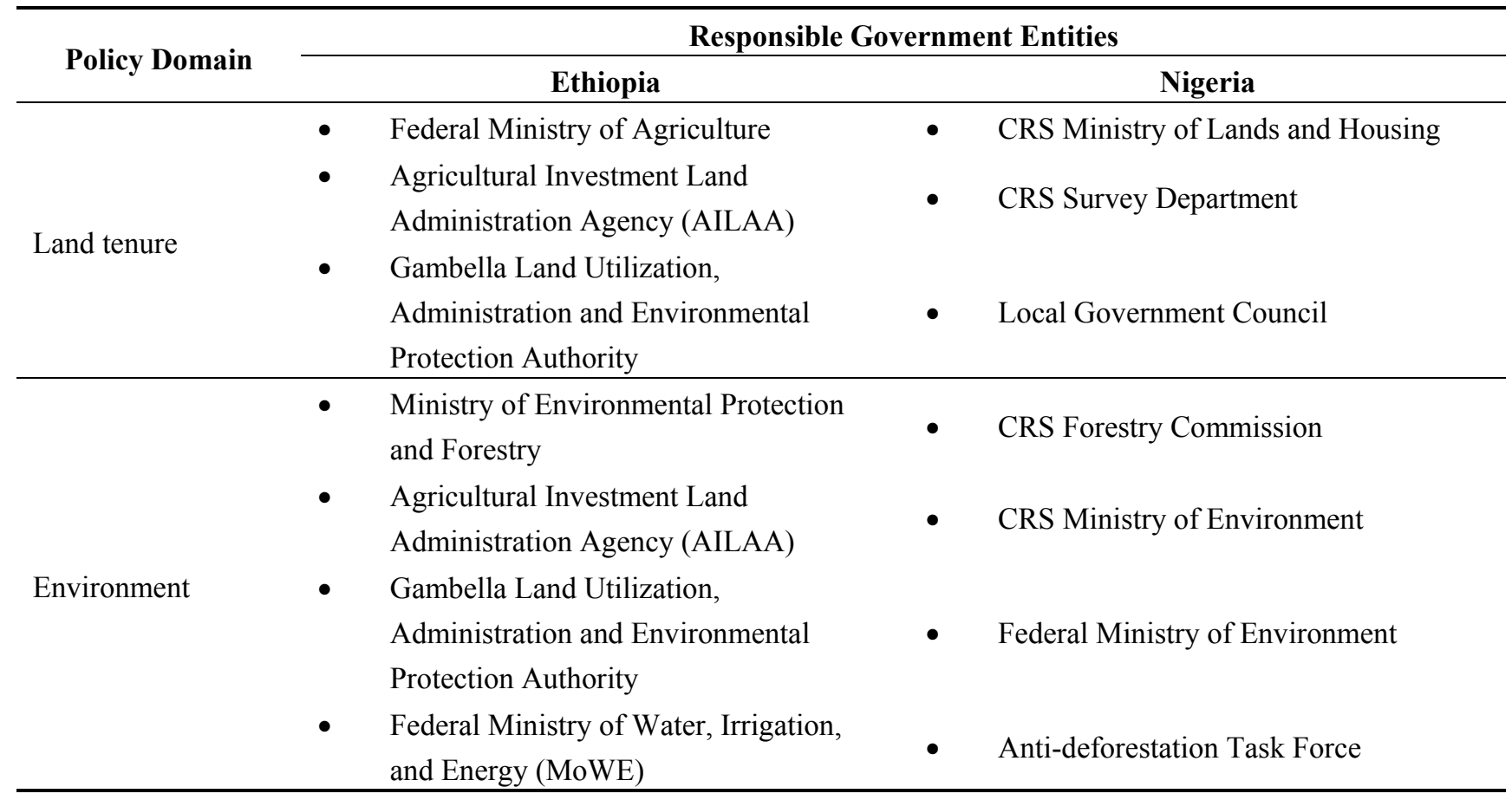

Note: All above entities were interviewed except for Nigeria's Federal Ministry of Agriculture and Rural Development.

\section{Policy Arrangements in Oban-Korup and Lower Baro-Akobo River Basin}

The following two sections analyze the sustainability performance of the four policy domains through a comparative perspective. This begins with an examination of each of the four policy domains in isolation and concludes with a discussion on their collective performance and a reflection on structural institutional challenges.

\subsection{Trade and Investment}

In both Ethiopia and Nigeria, the promotion of private agricultural investment is an explicit policy aim articulated through national-level strategies. When Nigeria reverted to Civilian Rule in 1999, economic instability and widening poverty gaps resulting from excessive reliance on oil revenues prompted the federal government to prioritize economic diversification. As is detailed in the National Planning Commission's 2003 National Economic Empowerment and Development Strategy (NEEDS) and later in the Ministry of Agriculture and Rural Development's (MOARD) 2012 Agricultural Transformation Agenda (ATA), the agricultural sector, which absorbs the largest proportion of Nigeria's economically active population, is considered a priority sector because of its employment-generating potential and low productivity. The overarching objective is to reduce the state's direct participation in agricultural production and service delivery that is said to be inefficient, subsidize corruption, and crowd out private investment. This involves privatization, market deregulation, and the introduction of investment incentives to promote greater private sector participation, which is to become the key impetus behind future modernization and commercialization of the sector. The Ethiopian federal government has similar objectives. Following the 1991 Revolution, Ethiopia's development policies 
were centered on enhancing smallholder productivity and the strengthening of domestic market linkages. However, due to the limited success of these strategies, in the $2000 \mathrm{~s}$ the federal government - for example, through the Ministry of Finance and Economic Planning's (MOFED) 2010 iteration of the five-year Growth and Transformation Plan (GTP) - increasingly began to prioritize trade-oriented commercial agriculture instead. The premise was that these could make meaningful contributions to both macro-economic and rural development objectives (e.g., by generating waged employment opportunities and through technology diffusion). This has involved the privatization of state farms and the introduction of various forms of support to investors, notably to export-oriented and capital-intensive investments in traditional cash crops cultivation such as cotton, sugarcane, oil palm, and rubber.

Regional autonomy in Ethiopia should theoretically enable regional and district governments to set their own policy agendas, particularly in peripheral regions with a weak revenue base, such as Gambella. However, high dependency on federal transfers limits the political space of Regional Councils, the apex planning and policy body in the regions, to define their own development priorities. In Gambella, for example, $85 \%$ to $90 \%$ of the annual regional budget is typically composed of federal subsidies. Although the Gambella Regional Council is controlled exclusively by Gambella's three main ethnic groups, Anuak, Nuer, and Majangir, their interests are organized into a single umbrella party, the Gambella People's Democratic Movement (GPDM), a regional ally of the ruling Ethiopian People's Revolutionary Democratic Front (EPDRF). In response to protracted inter-ethnic conflicts in Gambella, in 2003 the EPDRF abolished all political parties and replaced them with three ethnically homogenous People's Democratic Organizations (PDO), which collectively form the GPDM. Besides independent opposition candidates, in the 2005 and 2010 regional elections an organized opposition could not challenge the GPDM stronghold on Gambella polity. Although the 'highlanders' that dominate national politics are poorly represented in the Gambellan executive, the current political structure and high dependency on federal transfers implies that federal government continues to dictate regional policy processes. With one of the largest reserves of available land for commercial agriculture in Ethiopia, Gambella is integral to the realization of national policy objectives. Despite ethnic federalism, the Gambella regional government has little actual sovereignty to define its own investment policy.

In Nigeria's CRS, the share of federal government allocations in total budget expenditure is considerably smaller than it is in Ethiopia's Gambella, typically ranging from $25 \%$ to $35 \%$. Although its two civilian governors are both members of the ruling People Democratic Party (PDP), the federal government tends not to interfere in lesser strategic states such as CRS - partly since they lack oil reserves and are not a source of religious or ethnic conflict. Also due to comparatively open multi-party elections at the state level, individual governors in CRS are able to exert ample discretion over CRS planning and policy processes and are more inclined to engage in populist politics. Under the first civilian governor (1999-2007), the CRS government took a more reserved stance toward agricultural investment. Under the CRS Economic Empowerment and Development Strategy Document (CR-SEED I, 2004-2008), for example, priority was given to enhancing smallholder participation and productivity in crops with especially high potential to alleviate poverty, such as oil palm and cocoa, with government retaining a prominent role in input and service delivery. The current, more private-sector oriented governor (2007-present), quickly departed from these policies, contending that government participation in agriculture fostered corruption, and that smallholders lacked resources and capacity to meaningfully 
contribute to agricultural industrialization objectives. The 2009-2012 strategic plan (CR-SEED II), therefore, placed 'more adaptable' private agricultural investment at the center of the state's agricultural modernization and poverty alleviation objectives.

When the Nigerian federal government ceded the Bakassi Peninsula to Cameroon in 2008 following a judgment by the International Court of Justice, CRS became a non-littoral state (e.g., without offshore territory); thereby, losing their right to a share of national oil revenues derived from Nigeria's predominantly offshore oil reserves. This created new pressures to generate revenues internally from other sources. Agribusiness was seen as one of the most lucrative alternatives to oil for both immediate (e.g., through privatization) and long-term (e.g., through taxes) internal revenue generation, especially since rural communities are primarily engaged in informal, and, therefore nontaxable economic activities.

Within this political and polity context, IPAs are responsible for both promoting and facilitating these agricultural investments. In Ethiopia, this was the domain of the Ethiopian Investment Agency (EIA) until 2010. For foreign investors, the federal EIA used to be the first point of contact; as a "one-stop shop", supporting investors with administrative and bureaucratic issues, such as, for example, business incorporation and applying for business licenses and work permits. Subsequently, investors needed to liaise with regional affiliates of the EIA - in the case of Gambella that being the Gambella Investment Agency (GIA) - for support in investment establishment and implementation (e.g., acquiring land, labor affairs, and engagement with other regional and district-level authorities). Domestic investors tended to bypass the federal EIA entirely. Besides this promotional and facilitating role, the EIA and its subunit have no legal mandate regarding impact mitigation and co-benefit capture or to engage in post-implementation monitoring. In practice, neither the EIA nor the GIA, for example, made any tangible efforts to attract those investors that best align with regional development needs and priorities or to intervene in the case of local conflict. At both the federal and regional levels, there was a lack of a clear investment governance framework-with responsibilities pertaining to investment regulation limited to narrow and fragmented institutional mandates. As a result, there was no cross-accountability between government entities. This implied that most sectoral ministries had no awareness of the existence of most investment projects and investors were not held to account for their activities, resulting in widespread misuse of land for extractive purposes (e.g., logging, charcoal production).

In the absence of oversight and coordination, and considering the limited capacity of the GIA to take on regulatory responsibilities, in 2010 the functions of the GIA (and those of many other regional investment agencies) were centralized within a newly formed department in the Ministry of Agriculture (MOA), namely the Agricultural Investment Support Directorate (renamed in 2013 as the Agricultural Investment Land Administration Agency (AILAA)). Although the EIA would continue to provide basic administrative support, AILAA took over all promotional, facilitating, and regulatory duties to ensure closer alignment of agricultural investment with national policy. As a result, investments became subject to performance conditions, such as rate of expansion and output, and approval decisions were increasingly shaped by investment alignment with national priorities (e.g., in terms of crops and trade-orientation). The larger, more strategic investments came under scrutiny through biannual monitoring missions coordinated by AILAA. Through these missions, investors should technically be evaluated on the basis of seven self-defined criteria: conformance to the land rental contract, labor conditions, labor quantity, use of machinery, contribution to community development, infrastructure 
development, and conservation practices. However, in practice, AILAA is concerned only with investment output, rather than social and environmental performance or the establishment of productive linkages. For example, even though AILAA monitoring reports recognize negative local investment impacts in Gambella, investors were only reprimanded for failing to develop at the agreed rate. For this reason, 25 investment licenses were cancelled in the region in 2011. This reflects the decidedly macro-economic orientation of both the AILAA and GTP. The centralization of investment responsibilities also further undermines both the capacity of the Gambella regional government to define its own agricultural development trajectories and the regulatory discretion of regional ministries.

In Nigeria, early agricultural investments in CRS also lacked a clear regulatory framework. The federal IPA, the Nigeria Investment Promotion Commission (NIPC), had similar functions to the EIA, offering predominantly administrative and bureaucratic support. Until 2008, CRS did not actively promote agricultural investment, so it lacked any well-defined institutional structure to promote, facilitate, and regulate investment. Although a Privatization Council was established to oversee the privatization of state-owned rubber estates (since rubber was not considered a priority crop in terms of poverty alleviation), responsibilities for regulating investor practices remained highly fragmented. This resulted in a lack of oversight, coordination, and an absence of institutions that were expressly charged with capturing investment co-benefits. With the change of policy direction in 2008, a one-stop shop, the Investment Promotion Bureau (IPB), was established in CRS to promote and facilitate investments in the state. As a result, the state, through the IPB, began to aggressively target large agribusinesses and also to privatize the cocoa and oil palm estates that under the previous administration had been partitioned for smallholder exploitation. Although the IPB did seek to attract investments with high development capacity, unlike AILAA, the IPB was not assigned any regulatory responsibilities. Therefore, it does not evaluate investment performance or have any authority to intervene. However, since it maintains formal links with important sectoral ministries (e.g., planning, environment, land, and agriculture) through staff with explicit liaison roles, it does promote close vertical and horizontal intra-governmental coordination within CRS, albeit largely for supporting investors in the navigation of the institutional landscape. This has led the CRS Ministry of Agriculture and Natural Resources (MANR), for example, to leverage potential investment co-benefits by supporting the establishment of an oil palm outgrower scheme linked to one of the investments in the context of the state's Cross River Agriculture and Rural Empowerment Scheme (CARES). However, experience from early sensitization activities revealed that most smallholders engaged in oil palm production were not interested in participating, as investors were interested solely in purchasing fresh-fruit bunches. Since most oil palm communities are engaged also in extraction and marketing, selling fresh-fruit bunches would undermine local value addition.

Most other investors in Gambella and CRS were, however, disinterested in adopting similar schemes because they feared that the creation of an off-take market would promote estate theft. The lack of investor interest in such initiatives illustrates how productive integration does not often arise spontaneously, thus highlighting the need for more active intervention by relevant government entities.

Though not optimally exploited, the policy arrangement in CRS does provide a better foundation for co-benefit capture than does the one in Gambella, where the concentration of responsibilities with one federal department and lack of vertical and horizontal coordination restrict the capacity of regional government to design and implement such programs around new investments. Despite this, in the 
absence of clear mandates and incentives, in neither landscape is investor spillover potential optimally exploited.

\subsection{Land Use Planning}

In CRS, there have been no coordinated efforts to spatially plan economic activities. A few isolated projects initiated by local conservation CSOs have adopted participatory land-use planning methods to enable communities to better manage and conserve their forest resources. These, however, have no discernible bearing on land allocation patterns for agricultural investment. Although there are no formal rules within regional government for identifying and allocating suitable and available land for agricultural investment, in practice these activities are carried out by MANR. District government, which tends to be most knowledgeable of local land uses and challenges, is excluded from this process. With support from the IPB, MANR identifies those areas where agro-ecological and physical conditions are most conducive for the investor's production activities. Once an area has been identified, MANR and the IPB then, often in an informal capacity, liaise with the leadership of communities owning the land in question to evaluate willingness to alienate the land to investors and conditions for this (this process will be further explored in the next section). None of the actors involved in this land identification process are guided by a clear policy direction regarding land-use priorities. In practice, land allocation patterns are highly irregular, as illustrated by Figure 1. They are shaped largely by investor priorities; some, for example, favor forested areas to recuperate establishment costs through the harvesting of timber, some prefer former state farms due to established on-farm infrastructure, and some look for more strategically located community farmlands along key transportation corridors. This unregulated land allocation process implies that locations most appropriate for agricultural investment-for example, where investments can best contribute to specific local development challenges and not conflict with socially and environmentally significant land uses - are not adequately prioritized. This is exacerbated by conflicting rationalization narratives across and within relevant government departments; with some arguing that investments should be prioritized in high population density areas to enable investors to capitalize on a large labor pool, while others favor conversion of forestland due to their lack of revenue-generating potential.

While haphazard spatial development can partly be attributed to the lack of relevant formal rules, the ambiguous regulatory framework in relation to land-use planning also enables well-placed government actors and customary elites to profit from the allocation process. The Survey Department, for example, sought to develop a land-banking system, which would involve the systematic identification of suitable lands based on pre-established inclusion criteria. This initiative was blocked by MANR; allegedly because excessive transparency of the land alienation process would threaten to undermine established accumulation structures. Since the interests of key actors within MANR, IPB, and Governor's Office tend to converge (especially since some senior officials have responsibilities that span across these entities), they form an influential coalition capable of suppressing reform initiatives undesirable to them and intra-governmental dissent. 


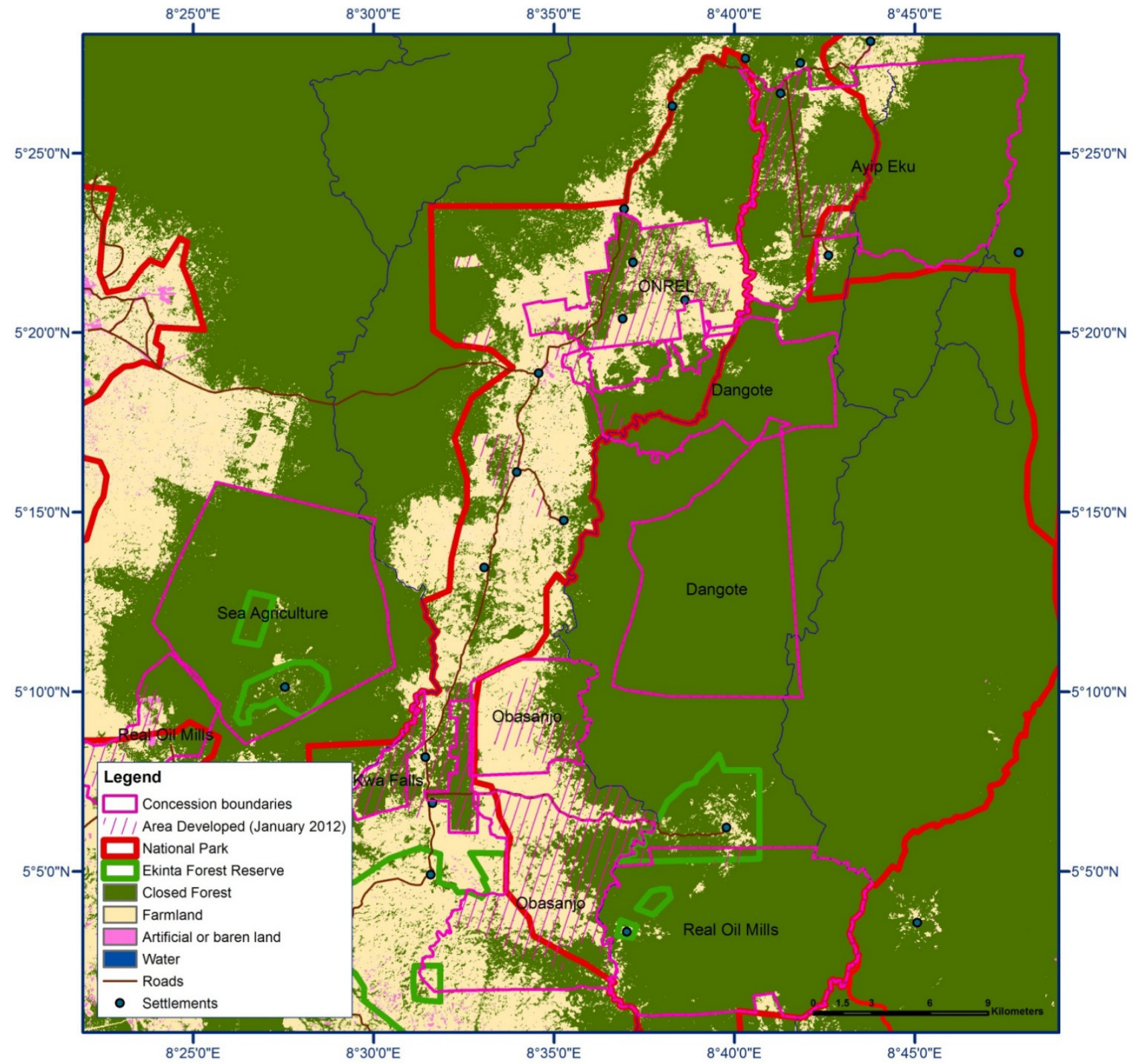

Figure 1. Land use within the Oban-Korup forest block. Source: Author's representation, based on NASA Landsat 5 satellite imagery ( $30 \mathrm{~m}$ resolution), Spot Image satellite imagery (5 m resolution), Field Research, CRS cadastral maps, and CRS Forestry Commission protected area maps. Reproduced from Schoneveld [38]; Note: "Areas developed" are those areas that have been converted for investment purposes by January 2012. "Artificial areas" are typically settlement and industrial development areas. 
Before 2010, similar dynamics were observable in Gambella. The GIA would help investors identify land that suited their needs, without accounting for conflicting land uses. Similar to CRS, other regional ministries and district government were entirely excluded from the land identification process. In some cases, investors had identified land on their own accord and the GIA merely facilitated the formalization of leasehold titles. The absence of clear land identification rules inspired corruption and the lack of a land-use planning mandate and capacity within the GIA resulted in overlapping land allocations and frequent land-use conflicts. Since the establishment of AILAA in 2010, all land identification activities in Gambella have been transferred to the federal level. Upon establishment, the Land Identification Group of AILAA began mapping suitable lands in Ethiopia through remote sensing analysis. District government and the newly established Land Utilization, Administration and Environmental Protection Authority that falls under the auspices of MOA and the Ministry of Environmental Protection and Forestry, were called on to assist in identifying any non-captured land-use conflicts. According to AILAA, only those lands free of forests, wildlife, and human settlement were included in the land bank. Through this process, 1,099,893 ha were earmarked for investment in Gambella. Although applied methods relied largely on satellite imagery and were not inclusive of local land users, earmarked lands tended not to include intensively farmed cropland. The inclusion, on the other hand, of large areas of forests in Abobo and Gog district, pastoral areas of Mekeuy and Jikawo district, and important wetlands such as the Duma Swamp, do highlight selective application of inclusion criteria in Gambella (Figure 2). Since AILAA is aware of these conflicts, this highlights that the issue is not capacity constraints, but rather federal development priorities, especially vis-à-vis conservation. In regards to conflicts over pastures, during this land-banking process, MOA, in collaboration with the Regional Council, was also actively involved in resettling agro-pastoral communities both within and outside investment lands into larger villages. This "villagization" initiative has both a political and social dimension; on the one hand, the federal government has little control over tribal pastoral communities, who are regularly involved in violent territorial and ethnic disputes, which it hopes to resolve through sedenterization. On the other hand, with these communities being highly dispersed within remote and poorly accessible areas, concentrating these will facilitate delivery of social services and infrastructure.

With the land identification process (and villagization) being a predominantly top-down approach originating from a one federal ministry that is central to the realization of Ethiopia's development strategies, regional actors do not meaningfully participate in the planning of their jurisdiction. However, with MOA currently developing Land Use Planning Guidelines and in late 2013 having commissioned an autonomous environmental protection institute to develop an integrated land-use plan for Gambella, important steps towards more rational land-use management in Gambella are being made. At this juncture it is too premature to evaluate the extent to which different land uses and locally defined development priorities will be incorporated. 


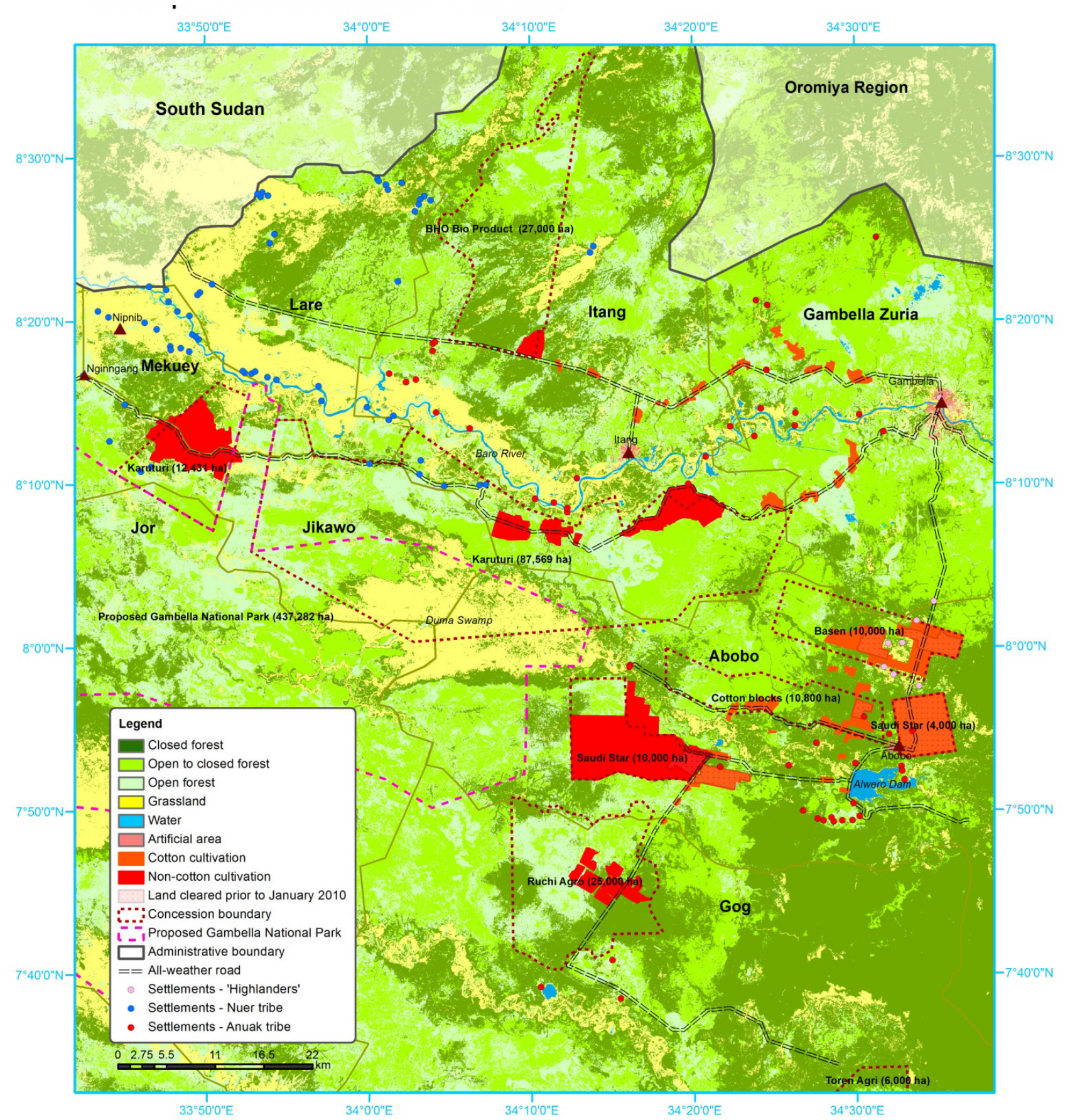

Figure 2. Land use within Lower Baro-Akobo River Basin. Source: Author's representation, based on NASA Landsat 5 satellite imagery (30 m resolution), GeoEye, field research, EWCA coordinates, and AILAA Provisional Land Lease Certificates. Note: "Artificial areas" are typically settlement and industrial development areas. "Non-cotton cultivation" are those areas that have been developed by commercial agriculture for crops other than cotton. 


\subsection{Land Tenure}

In both Ethiopia and Nigeria, all land is vested in the state and only user rights, as opposed to ownership rights, are recognized. State ownership of land is central to land policies in both countries, based on principles of social egalitarianism in which state land ownership is viewed as the most appropriate means to protect citizens from market forces and landed elites. In the absence of elaborate provisions that detail for what purposes the state can repossess land, there are no statutory obstacles to the state expropriating land for private investment. Although land laws in both countries recognize the right of individual land users to compensation in the case of expropriation, these are limited to unexhausted land improvements and they exclude common pool resources such as water and forests. In Nigeria, customary land rights are protected by law without requiring formalization, while in Ethiopia land users in practice require "proof of holding rights". In Ethiopia's more populous highlands, over $90 \%$ of smallholders received land certificates in the mid-2000s, typically for permanent farmland. In the lowlands, on the other hand, the prevalence of land-extensive production systems, such as pastoralism and flood-retreat agriculture, have complicated land certification premised on individualized landholdings and sedentary livelihood systems. Therefore, land users lack protection from expropriation, resulting in displacement from pastureland and "wet-season" farming areas. In the region, cultivation activities take place bi-annually: in the dry season on the riverbanks and in the wet season further inland when riversides become heavily waterlogged. Since most investment lands avoid the intensively farmed riversides, only wet season plots tend be affected. This has resulted in declining agricultural output amongst dispossessed communities, and territorial encroachment, which generates violent conflicts between agro-pastoral sub-tribes over pastureland.

In CRS, there is a clear tendency to avoid land within customary land areas where land users have the right to compensation. Historically, forcible acquisition of customary land in the area has resulted in protracted conflicts over (non-) payment of compensation, making such land acquisitions not only a politically contentious issue, but also subject to complicated valuation procedures and lengthy legal disputes that are likely to delay investment. As a result, investors and government prefer to acquire land that is technically under direct state administration. These include, for example, lands located within protected areas and land previously alienated for commercial farming to the state, something that happened mostly during the colonial and early post-Independence era (early 1900s to mid-1960s). However, this does not imply that investments do not conflict with community farmlands. For example, most state farms in Nigeria were abandoned or neglected by the late 1970s as a result of civil conflicts, and mismanagement and exploitation of plantations for political and personal ends. Government officials and contractors managing the estates had during that time allocated both the developed and also the undeveloped parts of the estate, which typically comprise the majority of estate land, for agricultural purposes to the rapidly expanding populations of surrounding communities and to the large, predominantly migrant, workforce that had largely been retrenched and, increasingly disenfranchised from their homelands, who were in pursuit of alternative livelihood activities within CRS. By the early 2000s, these estates therefore had been entirely absorbed into a densely populated agricultural landscape. These opaque allocations became a source of rampant corruption within MANR. Similarly, many of the forest reserves peripheral to the Oban-Korup forest block, though under administration of the Forestry Commission, were allocated to both indigenous and migrant communities for similar 
purposes under the Taungya forest plantation system introduced in the 1980s to replenish the reserves' timber stock. Although the system failed, the Forestry Commission continued allocating lands within the reserves as a source of revenue, which it shared with local chiefs. Since the allocation of both the reserves and the estates took place in an extra-legal context, those households that had become reliant on that land were, without due recourse, systematically evicted when the reserves and estates were allocated to new investors.

In both Ethiopia and Nigeria, statutory law does not recognize the right to community consultations and consent when land is expropriated. In Ethiopia, land was therefore acquired and allocated without the prior knowledge or participation of populations concerned. In Nigeria, on the other hand, the buy-in of traditional authorities is actively sought, despite these authorities having lost most land management prerogatives under the 1978 land reform and most acquired lands technically being state-owned. Since much of the rural CRS population is alienated from the state and consider the government as a self-serving institution, traditional authority structures offer the most tangible platform for political participation in the region. Because local chiefs wield considerable political leverage, both district and regional governments are reluctant to antagonize them, and therefore seek their endorsement in case of land acquisitions. This relationship serves to suppress local resistance and absolves government and investors from responsibility in case of conflict.

However, the negotiations between investors, officials from the IPB and MANR, and chiefs tend to be highly opaque. Through payment of sizeable "traditional rites" fees, they typically serve to co-opt chiefs. Often investors are also encouraged to make annualized royalty payments to chiefs, which, due to their high personal entitlement to land proceeds, is in the vast majority of cases used exclusively for individual rather than for community purposes. Despite having fiduciary duties, chiefs rarely solicit inputs or seek the consent of their communities - decisions in practice are heavily centralized within the Chiefs' and Elders' Councils and exclude other important social groups represented by, for example, the Youth and the Women's Councils. Due to entrenched social hierarchies, these groups readily defer to and rarely contest decisions made by chiefs. In a number of cases where youth groups resisted investment activities, conflicts ended as a result of chiefs' interventions but without resolving underlying issues. Moreover, a number of organized resistance campaigns coordinated by local human rights groups were crippled when chiefs' and political interference eroded the public support base.

Although district-level government could arguably be better positioned to represent local communities, in CRS, there is negligible cross-accountability between region and districts. With the state government systematically refusing to fully share internal revenues with district governments, despite that being a constitutional requirement, less than $2 \%$ of district income is derived from regional sources. This results in district government being chronically underfunded and operating largely in isolation from the state government. Even though district governments have been assigned important land management functions under Nigeria's land reform, because substantial rents can be captured through the land acquisition and allocation process, these functions have become concentrated within state government, causing many key investment districts in CRS to close down their land management departments.

These social and political dynamics have a debilitating effect on downwards accountability structures. Chiefs and state government officials benefitting from the land acquisition process are able to extract rents with impunity and investors have no incentives to invest in community relations and development since relations are mediated by co-opted customary elites. 
Although the land acquisition process in Ethiopia is less inclusive of the regional government and customary authorities than it is in Nigeria, since all relevant responsibilities fall wholly under AILAA, downwards accountability structures are similarly weak. Since the government, as per land leasehold contracts signed with investors, is responsible for ensuring land is "free from impediment", investors have no incentive to accommodate local communities, turning therefore to federal government to assuage discontent. When a number of displacement-related conflicts emerged, all communities conferred with the chairman of the Kebele, the lowest level of government. This chairman, a government employee, is the village-level link with government. However, due to power being strongly centralized with the federal government and because of the lack of separation between the state and the party apparatus, especially in Gambella where opposition parties have been banned, this chairman tends to follow EPDRF policy direction. Without any real intervention capacity, the chairman refers these issues to district government, though these similarly lack the necessary capacity or authority to resolve conflicts.

In most cases, district government has no knowledge of the location of land that is earmarked for or already been allocated for investment. The loss since 2010 of discretionary authority over investors is an obvious source of frustration for district government, especially as many investors are increasingly drawing on district government to address operational issues (e.g., recruitment, infrastructure development). Nevertheless, since district government is the primary recipient of land rents paid by investors, amounting in some cases to more than half the total annual budget, they are often compelled to enable rather than obstruct investment activities. Aggrieved land users are as a result frequently reprimanded for being "anti-development" and "anti-government". Even though AILAA is often informed of conflicts through its monitoring missions, since they lack a representation mandate and MOA is intent on modernizing local production practices in its peripheral regions through villagization and plantation employment, they are disinclined to curb conflicts with traditional land users. Arguably, by reducing the long-term viability of existing production systems, many land users are pushed into embracing production systems that are in line with MOA policy.

\subsection{Environment}

In both countries, most investment projects should conduct a mandatory environmental and social impact assessment (ESIA) before commencing any land development activities. Typically conducted by independent consultants, the objective of the assessment is to identify potential socio-economic and environmental impacts of the proposed project in order to develop appropriate impact mitigation mechanisms and environmental management plans (EMP). Since ESIA regulations across the continent are typically a product of external technical support and international treaties, they tend to be modeled after international best practices. Not being a product of internal pressures and processes, the virtue of this instrument is in both countries, however, poorly institutionalized and is largely perceived as obstructive to development. As a result, environmental protection agencies charged with reviewing the ESIA reports, allocating environmental permits, and monitoring and evaluating investments on the basis of EMP commitments, are not considered to be budgetary priorities and thus lack both monitoring and enforcement capacity. In Gambella, only $24 \%$ of projects had completed an ESIA. With the Ministry of Environmental Protection and Forestry responsible for the ESIA process lacking capacity, and the GIA not mandated to ensure investors followed environmental laws, before 2010 no investors had completed 
an ESIA. Even though AILAA, whose "environment directorate" is comprised of only two staff at the time of research, lacks the necessary expertise, upon establishment they took over all ESIA evaluation and monitoring responsibilities from the Ministry of Environmental Protection and Forestry. AILAA now requires investors to submit an ESIA report within three months of signing the leasehold agreement. Despite this, large foreign investors in Gambella only submitted ESIA reports between one to two years following the commencement of project activities, highlighting that AILAA is not strictly enforcing ESIA regulations and leasehold agreements. Although AILAA indicated that the EMP contained with the ESIA informs their performance monitoring activities, none of AILAAs monitoring reports makes any reference to the EMP; selectively applying only the aforementioned seven indicators (Section 4.1). ESIAs are seen merely as technicalities, as illustrated by the sequence of ESIA applications. For example, one of the underlying objectives of the ESIA process is to identify those production sites and practices that are least destructive and that best contribute to local needs. If they are conducted after land has been allocated and production activities have commenced, this cannot be achieved, raising very real questions about the utility of the ESIA process in the Ethiopian context. Most companies that had started fulfilling these legal obligations only did so when they were seeking financing from the Development Bank of Ethiopia, which is conditional on ESIA submission. As a result of weak enforcement, most companies engage in clear-cutting of forests, draining of wetlands, and unregulated water extraction, as also acknowledged in AILAA monitoring reports.

Despite shortcomings in the ESIA process, the ESIA reports can be useful sources of information for other regional actors. Among these are the Ethiopian Wildlife Conservation Authority (EWCA) when they wish to develop wildlife management plans and to gazette areas for strict conservation purposes, the Land Utilization, Administration and Environmental Protection Authority wishing to carry out environmental audits, district government wishing to develop complementary infrastructure projects, and non-governmental organizations wishing to engage in human rights campaigns. These actors were all refused access to the ESIA reports by AILAA, despite environmental laws requiring that such reports be made publically accessible. Many stakeholders contend that publicizing information on projects' risks and investor commitments and practices would enable civil society and other groups to hold investors accountable for weak social and environmental performance, thereby potentially obstructing the project establishment process.

In CRS, only one out of 20 companies that required an ESIA had obtained an environmental permit. Since the ESIA process is considered excessively time-consuming and expensive, the state Ministry of Environment does not enforce associated legislation. Not only does the Ministry view it as "investment-unfriendly", it claims that the required federal procedures, notably the community consultations and public hearings, conflict with the interests of stakeholders involved in the land acquisition process. In particular they fear that such platforms would bring informal agreements and negotiations under public scrutiny. A dedicated department has therefore not been established. The state Ministry of Environment tends to defer to the federal Ministry of Environment that has the sole authority to allocate environmental permits. However, the federal ministry in turn relies entirely on the state-level ministry to ensure regulations are respected and EMPs are enforced. In the absence of formal upwards accountability structures, the state-level ministry in practice operates autonomously, so most companies are able to bypass federal environmental regulations without repercussion. The one company that did follow the required ESIA procedures did so not out of domestic pressures, but rather to fulfill 
requirements of the Roundtable on Sustainable Palm Oil (RSPO) that its members respect national laws. In the absence of oversight, many projects engage in clear-cutting of natural vegetation and neglect to adopt effluent management procedures for their processing plants. A number of rubber and oil palm processors were, for example, discharging wastewater into nearby waterways.

Even though Ethiopia's environmental policies recognize the importance of adequately reconciling conservation and development objectives, in practice environmental concerns within important government entities such as MOA and the Ministry of Water, Irrigation, and Energy and lower tiers of government are limited to those that have direct bearing on agricultural productivity. Authorities like EWCA that are genuinely committed to conserving Gambella biodiversity and adhering to national policies, therefore have scant political leverage, either regionally or federally, and are largely excluded from policy-making processes.

In CRS, on the other hand, environmental objectives figure more prominently in both official and unofficial government rhetoric, with the current administration running not only on a platform of private-sector development but also on a conservation one. For example, in an effort to curb deforestation, the state government introduced a deforestation moratorium and signed agreements with the federal government and the United Nations on participation in the Reducing Emissions from Deforestation and Forest Degradation (REDD+) initiative. To ensure enforcement, an anti-deforestation taskforce was established that reports directly to the governor. Curiously, as illustrated also by Figure 1, most investments fully or partially conflict with dense tropical forests. Although the taskforce is infamous for their aggressive confiscation and persecution tactics, as yet they have not confronted companies that are openly clear-cutting, but do systematically detain small-scale chainsaw loggers. The moratorium is clearly enforced only selectively. Whether this is a product of political interference or corruption, or both, is unclear.

Moreover, at least 10 projects were allocated land within forest reserves or national parks, covering an area of at least 57,855 ha; further illustrating that the state's conservation rhetoric is large cosmetic. This renders many land allocations illegal, since the forest reserves should first have been de-gazetted by the Forestry Commission and the national park by the federal government. The head of the state Forestry Commission and head of the Nigeria National Parks Services (NNPS) both acknowledged this situation, though they expressed reluctance to intervene for fear of job security due to the complicity of key government officials in enabling these illegal transfers. In addition, proponents of most CRS investment projects have ample political and economic clout - a number of projects are, for example, owned by a former senator, a former Nigerian president, Africa's richest person, and the world's largest oil palm company. So even when the state's governor was made aware of this study's findings he failed to take corrective action. With a number of senior officials within the state administration also employed by these companies as "consultants", the tenuous separation between private and public interests in CRS creates conflicts of interest and reduces the intervention capacity of the state.

\section{Discussion}

The analysis shows that the existing policy arrangements within the four researched policy domains fail to effectively mitigate potentially negative investment outcomes or capture locally relevant investment co-benefits. Locally important land uses are displaced without consultation or consent of 
affected communities; high conservation-value landscapes are converted to plantation monoculture; environmentally destructive production practices are not curtailed; and co-benefits related to, for example, technical diffusion, enhanced availability of inputs, and improvement of local market articulations are not being captured. As a result, these new investment landscapes can be characterized by fundamental conflicts between economic growth objectives on the one hand, and social equity and environmental protection objectives on the other. This clashes with sustainable landscape principles premised on the integration of diverse actor and sectoral interests and objectives.

This can be attributed to a host of factors. In CRS, the ability of both customary and political elites to capture and extract rents from the land allocation process and the blurring of public-private boundaries fosters co-optation and reduces the political will and capacity to effectively regulate investment. As a result, the interests of powerful regional groups have become neatly aligned with the interests of private capital; further entrenching special interest politics and traditional power and accumulation structures. While similar processes were evident in Gambella in the past, the centralization and concentration of all investment promotion, facilitation, and regulation responsibilities within a single government department has largely eliminated corrupt practices. This, however, has resulted in one department narrowly focusing on modernizing and commercializing agriculture being assigned those responsibilities that should be spread across multiple specialized policy domains. This severely undermines the capacity of other stakeholders to exercise oversight over agricultural investments and to shape regional development priorities and trajectories, in turn conflicting with constitutional principles of ethnic federalism.

Albeit through highly divergent causal pathways, the sustainability outcomes in both of these investment landscapes exhibit striking similarities. The investment and trade policy domain is increasingly undermining policy objectives within the three other policy domains, rather than establishing synergies across domains. Although findings highlight a number of specific and highly contextual challenges within these two specific investment landscapes, they also highlight a number of important lessons for landscape governance, more generally. These relate in particular to structural institutional conditions within the government administration that need to be fulfilled in order to develop an appropriate landscape governance regime. Four conditions were identified:

(1) Mandate: within a landscape governance system, institutional mandates need to be clearly defined and divided amongst those ministries and levels of government that oversee applicable policy domains. These mandates would need to be grounded in formal rules and encompass those roles and responsibilities detailed in section 3 pertaining to impact mitigation and co-benefit capture. As illustrated by the CRS case study findings, lack of clarity in this leads to inadequate regulatory oversight over investments and enables well-placed officials to craft new informal rules to suit individual accumulation objectives. Conversely, in the case of Ethiopia, the concentration of both promotional and regulatory mandates within a single policy domain inevitably creates situations where one of the two mandates is compromised or selectively enforced. The uneven distribution of power that enables certain actors to capture some policy and regulatory processes can be partly attributed to overlapping and unclear distribution of institutional mandates. 
(2) Capacity: In order to meet assigned mandates, those responsible require both the necessary human and financial resources. This is well illustrated by the acute lack of enforcement capacity by environmental ministries and agencies in both regions. The case studies also illustrate that in addition to resources, stakeholders within "low-priority" policy domains and lower-levels of government that have clear constitutional mandates and representation functions need to have the necessary capacity to adequately act upon granted authority. The fulfillment of the other three institutional conditions would safeguard against intra-governmental power manipulation that undermines institutional discretion over policy-making and implementation.

(3) Accountability: Clear and well-functioning accountability structures provide those internal and external checks and balances that restrict government actors from abusing power differentials and operating outside the confines of assigned mandates. This would involve clearly defined consequences for indiscretion or underperformance. Case study findings also highlight a number of structural challenges. For example, CSOs and community groups could play an important countervailing role, but are unable to exert any meaningful influence since they lack information. In both case studies, governments purposefully restrict public access to crucial sources of information, such as ESIAs, cadastral maps, monitoring reports, and terms of land alienation. Improved transparency and access to such information sources would improve CSO capacity to hold relevant stakeholders accountable. Additionally, there is no meaningful downward accountability of traditional authorities (in the case of CRS) and government agencies towards affected persons. In many cases this would require the introduction of new rules relating to allocation of fiduciary duties, community consultations, community consent, and accessibility and availability of impartial and independent conflicts resolution platforms. Lastly, the case studies highlight weak collaboration between ministries and levels of government, thereby reducing the capacity to adequately capitalize on sectoral expertise and designing and implementing complementary initiatives. Improving cross-accountability between public institutions requires clear procedural rules on information sharing, consulting, and shared budget allocations.

(4) Incentives: Improvement of incentive structures involves both the removal of existing undesirable incentives and the introduction of new incentives. Undesirable incentives include those perverse and distortionary incentives that enable and even encourage well-placed policy-makers to allocate socially and environmentally significant lands to investors. These incentives are partly economic (e.g., improved revenue generation through income tax and land rents, corruption), political (e.g., extending territorial authority over peripheral spaces), and ideological (e.g., the virtues of modern agriculture vis-à-vis traditional production systems). Clear separation of responsibilities and improved accountability structures could partly resolve these issues. Most importantly, the performance of public institutions responsible for specific policy domains should be evaluated on the basis of accomplishments in relation to realizing concrete performance indicators that are aligned to well-defined strategic plans. Although these could be partly informed by cross-sectoral and landscape-level policies, clarity of mandate requires sector- and, in some cases, issue-specific policies, plans, and strategies. 
Considering the powerful vested interests in maintaining the status quo, a global political economy that promotes private sector-led development and deregulation, and national policies that often place excessive faith in the modernization project, realizing these four conditions will be no easy feat. Regardless, they should still be viewed as some of the foundational pre-conditions for sustainable landscape governance. Once established, this would facilitate the effective implementation of important cross-sectoral initiatives such as participatory and integrated land-use planning, public-private co-regulatory initiatives, and institutional innovations that aim to operationalize and upscale adoption of market-based instruments such as, for example, voluntary certification schemes like the RSPO and codes of conducts like the Voluntary Guidelines on the Responsible Governance of Tenure (VGGT) or the OECD Guidelines for Multinational Enterprises. In these case studies and across Africa more generally, such innovations have not played a notable role to date in shaping investor conduct or in institutionalizing best practice principles within government [4]. Although some of these global governance instruments could fill regulatory and implementation gaps within landscapes, since they are principally concerned with reducing the negative investment footprint rather than fostering green and inclusive growth, they should be embedded in and aligned to national and subnational policy processes rather than just make up for governance shortcomings.

The establishment of inclusive and participatory multi-stakeholder platforms at the landscape-level that involve civil society, the private sector, and government stakeholders could serve to identify institutional and regulatory reform needs, priorities, and modalities - ideally, guided by results of a participatory diagnostic process. The formation of domain-specific working groups within such platforms would ensure sector-relevant issues are captured. These platforms and working groups could act as focal points for operationalizing international best practice principles and cross-sectoral initiatives. Such structures would also help channel and harmonize donor-funded initiatives. Positive experiences from National Contact Points (NCP) in Europe to support the implementation of the OECD Guidelines on Multinational Enterprises also suggest that investment-specific programs may be desirable, especially within investment landscapes. NCPs provide implementation support, assist in resolving conflicts arising from corporate non-compliance, and also publicize information on non-compliance. Within developing country contexts, where access to information and to sufficiently independent conflict resolution channels is often lacking, such programs could serve to level the playing field by improving accountability structures and transparency. The mandate of NCP-type programs could be expanded by aligning and harmonizing a wide range of initiatives seeking to improve corporate performance, such as the Africa Land Policy Initiative's Principles on Large-Scale Land Based Investment (LSLBI), the World Bank-led Principles on Responsible Agricultural Investment (PRAI), and the United Nations' Guiding Principles on Business and Human Rights. Moreover, they could assist investors pursuing sustainability certification and supporting civil society groups seeking to issue complaints.

\section{Conclusions}

Findings highlight that integrated, cross-sectoral policies aiming to reconcile landscape-specific challenges and diverse actor interests are unlikely to produce meaningful sustainability outcomes without a rigorous diagnosis of policy arrangements within pertinent policy domains. As is summarized 
in the Discussion, numerous structural institutional challenges undermine the capacity of individual policy domains to adequately fulfill their potential roles. Although this paper focused on large-scale agricultural investment, observed processes can play out in diverse contexts. When introducing any other productive land use that is likely to compete with existing land uses, such as, for example, mining, infrastructure, and forestry projects, governments will need to contend with similar institutional challenges. Systematic analysis of institutional mandates, capacities, accountabilities, and incentives could contribute to identifying institutional reforms needs and priorities. Most sustainability interventions in investment landscapes, especially those that aim to involve multiple sectors, actors, and scales, will not produce intended outcomes without the establishment of these institutional fundamentals.

Although the emerging discussion on global governance shifts is increasingly pointing to the more prominent co-regulatory role of non-state actors, this research does not observe any meaningful participation of non-state actors within or alignment of international co-regulatory initiatives with relevant policy domains. When these do have bearing on outcomes, it tends to be through peripheral rather than embedded processes. Instead, what the case studies illustrate is that when higher-level strategic interests are at play, there is a tendency to centralize and concentrate policy formulation and implementation processes within key governmental power nodes. This in turn undermines the discretionary authority of subordinate policy domains such as land tenure and environment, the autonomy of local government, and civil society participation. This signifies a regression with respect to achieving ideal-typical landscape governance modes that involve multiple actors, scales, and sectors.

Although the frontiers of Ethiopia and Nigeria are in many ways unique, considering how the contemporary political economy in many African countries is strongly shaped by deeply entrenched societal disparities, patrimonial accumulation, and highly modernist development discourse, similar patterns are likely to be observable elsewhere. This suggests a need for greater nuance in the global governance debate and calls for closer examination of the spatial variations and conditions that give rise to these new modes of governance for sustainable development.

\section{Acknowledgments}

The author would like to acknowledge field research support from Maru Shete in Ethiopia (St. Mary's University) and Emmanuel Owan in Nigeria (Development in Nigeria). Funding for research activities was provided by the Center for International Forestry Research (CIFOR).

\section{Author Contributions}

The author is the sole contributor to this article.

\section{Conflicts of Interest}

The author declares no conflict of interest. 


\section{References}

1. Cotula, L. The international political economy of the global land rush: A critical appraisal of trends, scale, geography and drivers. J. Peasant Stud. 2012, 39, 649-680.

2. Schoneveld, G.C. The Governance of Large-Scale Farmland Investments in Sub-Saharan Africa: A Comparative Analysis of the Challenges for Sustainability; Eburon: Delft, The Netherlands, 2013.

3. Deininger, K. Challenges posed by the new wave of farmland investment. J. Peasant Stud. 2011, $38,217-247$.

4. Schoneveld, G.C. The geographic and sectoral patterns of large-scale farmland investments in sub-Saharan Africa. Food Policy 2014, 48, 34-50.

5. Fan, S.; Saukar, A. Public Spending in Development Countries: Trends, Determination and Impact; International Food Policy Research Institute: Washington, DC, USA, 2006.

6. World Bank. Rising Global Interest in Farmland: Can it Yield Sustainable and Equitable Benefits? World Bank: Washington, DC, USA, 2011.

7. Lavers, T. "Land grab" as development strategy? The political economy of agricultural investment in Ethiopia. J. Peasant Stud. 2012, 39, 105-132.

8. Schoneveld, G.C.; Zoomers, A. Natural resource privatization in sub-Saharan Africa and the challenges for inclusive green growth. Int. Dev. Plan. Rev. 2015, 37, 95-117.

9. De Schutter, O. How not to think of land-grabbing: Three critiques of large-scale investments in farmland. J. Peasant Stud. 2011, 38, 249-279.

10. Hagmann, T.; Péclard, D. Negotiating statehood: Dynamics of power and domination in Africa. Dev. Chang. 2010, 41, 539-562.

11. German, L.A.; Schoneveld, G.C.; Mwangi, E. Contemporary Processes of Large-Scale Land Acquisition in Sub-Saharan Africa: Legal failures, or Elite Capture of the Rule of Law? World Dev. 2013, 48, 1-18.

12. Kozar, R.; Buck, L.E.; Barrow, E.G.; Sunderland, T.C.H.; Catacutan, D.E.; Planicka, C.; Hart, A.K.; Willemen, L. Toward Viable Landscape Governance Systems: What Works? EcoAgriculture Partners: Washington, DC, USA, 2014.

13. Sayer, J.; Sunderland, T.; Ghazoul, J.; Pfund, J.L.; Sheil, D.; Meijaard, E.; Venter, M.; Boedhihartono, A.K.; Day, M.; Garcia, C.; et al. Ten principles for a landscape approach to reconciling agriculture, conservation, and other competing land uses. Proc. Natl. Acad. Sci. USA 2013, 110, 8349-8356.

14. Pahl-Wostl, C. A conceptual framework for analysing adaptive capacity and multi-level learning processes in resource governance regimes. Glob. Environ. Chang. 2009, 19, 354-365.

15. Bäckstrand, K. Multi-stakeholder partnerships for sustainable development: Rethinking legitimacy, accountability and effectiveness. Eur. Environ. 2006, 16, 290-306.

16. Görg, C. Landscape governance: The "politics of scale" and the "natural" conditions of places. Geoforum 2007, 38, 954-966.

17. Prieto-Carrón, M.; Lund-Thomsen, P.; Chan, A.; Muro, A.; Bhushan, C. Critical perspectives on CSR and development: What we know, what we don't know, and what we need to know. Int. Aff. 2006, 82, 977-987. 
18. Kolk, A.; van Tulder, R. Poverty alleviation as business strategy? Evaluating commitments of frontrunner multinational corporations. World Dev. 2006, 34, 789-801.

19. Utting, P. Rethinking Business Regulation: From Self-Regulation to Social Control; UNRISD Programme Paper TBS-15; United Nations: Geneva, Switzerland, 2005.

20. Scherer, A.G.; Palazzo, G. The new political role of business in a globalized world: A review of a new perspective on CSR and its implications for the firm, governance, and democracy. J. Manag. Stud. 2011, 48, 899-931.

21. Lange, P.; Driessen, P.P.; Sauer, A.; Bornemann, B.; Burger, P. Governing Towards Sustainability - Conceptualizing Modes of Governance. J. Environ. Policy Plan. 2013, 15, 403-425.

22. Driessen, P.P.; Dieperink, C.; Laerhoven, F.; Runhaar, H.A.; Vermeulen, W.J. Towards a conceptual framework for the study of shifts in modes of environmental governance-Experiences from The Netherlands. Environ. Policy Gov. 2012, 22, 143-160.

23. Matthews, R.; Selman, P. Landscape as a focus for integrating human and environmental processes. J. Agric. Econ. 2006, 57, 199-212.

24. Holmgren, P. On Landscapes_Part 2: What are landscapes. 2014. Available online: http://blog.cifor.org/19791/on-landscapes-part-2-what-are-landscapes (accessed on 14 October 2014).

25. Marshall, G.R. Polycentricity, reciprocity, and farmer adoption of conservation practices under community-based governance. Ecol. Econ. 2009, 68, 1507-1520.

26. Ostrom, E. Beyond markets and states: Polycentric governance of complex economic systems. Am. Econ. Rev. 2010, 100, 641-672.

27. Elbakidze, M.; Angelstam, P.; Sandström, C.; Axelsson, R. Multi-stakeholder collaboration in Russian and Swedish model forest initiatives: Adaptive governance toward sustainable forest management? Ecol. Soc. 2010, 15, 1-20.

28. Arnouts, R.; van der Zouwen, M.; Arts, B. Analysing governance modes and shifts-Governance arrangements in Dutch nature policy. For. Policy Econ. 2012, 16, 43-50.

29. Jones, C.; Hesterly, W.S.; Borgatti, S.P. A general theory of network governance: Exchange conditions and social mechanisms. Acad. Manag. Rev. 1997, 22, 911-945.

30. Hajer, M.A.; Wagenaar, H. Deliberative Policy Analysis: Understanding Governance in the Network Society; Cambridge University Press: Cambridge, UK, 2003.

31. Arts, B.; Leroy, P.; van Tatenhove, J. Political modernisation and policy arrangements: A framework for understanding environmental policy change. Public Organ. Rev. 2006, 6, 93-106.

32. Liefferink, S.R.D. The dynamics of policy arrangements: Turning round the tetrahedron. In Institutional Dynamics in Environmental Governance; Springer: New York, USA, 2006; pp. 45-68.

33. Ward, H. Responsible Enterprise, Foreign Direct Investment and Investment Promotion; International nstitute for Environment and Development: London, UK, 2008.

34. Oates, J. Myth and Reality in the Rain Forest: How Conservation Strategies are Failing in West Africa; University of California Press: Berkeley, CA, USA, 1999.

35. Kamdem-Toham, A.; D’Amico, J.; Olson, D.; Blom, A.; Trowbridge, L.; Burgess, N.; Thieme, M.; Strand, H. A Vision for Biodiversity Conservation in Central Africa: Biological Priorities for Conservation in the Guinean-Congolian Forest and Freshwater Region: Annex A; World Wide Fund for Nature: Libreville, Gabon, 2006. 
36. Woube, M. Flooding and sustainable land-water management in the lower Baro-Akobo river basin, Ethiopia. Appl. Geogr. 1999, 19, 235-251.

37. Pearce, F. Agribusiness boom threatens key African wildlife migration. Yale Environ. 2011, 360, $1-3$.

38. Schoneveld, G.C. The politics of the forest frontier: Negotiating between conservation, development, and indigenous rights in Cross River State, Nigeria. Land Use Policy 2014, 38, 147-162.

(C) 2014 by the authors; licensee MDPI, Basel, Switzerland. This article is an open access article distributed under the terms and conditions of the Creative Commons Attribution license (http://creativecommons.org/licenses/by/4.0/). 